\title{
Desain Finite State Automata Untuk Merancang Vending Automata Logam Mulia
}

\author{
Susanto Susanto ${ }^{1,}{ }^{*}$, Venny Yulianty ${ }^{1}$, Bobby Suryo Prakoso ${ }^{1}$, Suwanda Suwanda ${ }^{2}$, \\ Windu Gata ${ }^{1}$, Kresna Ramanda ${ }^{1}$ \\ 1 IImu Komputer; Universitas Nusa Mandiri; Jalan Jatiwaringin No. 2, Cipinang Melayu, Jakarta \\ Timur; (021)8005722; e-mail: 14207082@nusamandiri.ac.id, 14207082@nusamandiri.ac.id, \\ bobby.byp@nusamandiri.ac.id, windu@nusamandiri.ac.id, kresna.kra@nusamandiri.ac.id \\ 2 IImu Komputer; Universitas BSI; Kampus Kramat 98 Jl. Kramat Raya No.98, Senen, Jakarta \\ Pusat 10450; (021) 23231170, Fax. (021) 21236158; e-mail: suwanda.sdz@bsi.ac.id \\ * Korespondensi: e-mail: 14207082@nusamandiri.ac.id
}

Diterima: 18 Agustus 2021; Review: 08 September 2021; Disetujui: 09 September 2021

Cara sitasi: Susanto S, Yulianty V, Prakoso BS, Suwanda S, Gata W, Ramanda K. 2021. Desain Finite State Automata Untuk Merancang Vending Automata Logam Mulia. Bina Insani ICT Journal. Vol. 8 (2): 113-122.

\begin{abstract}
Abstrak: Menabung logam mulia merupakan investasi yang dianggap safe haven, ditengah era modern saat ini menabung logam mulia dapat dilakukan dengan cara dicicil, sedangkan yang menjadi masalahnya adalah kekhawatiran ketika fisik logam mulia tidak dapat ditarik fisiknya yang membuat potensi fraud atau investasi bodong yang sedang marak saat ini, untuk mengatasi masalah itu penjualan logam mulia dapat dikembangkan menjadi lebih menarik dengan vending machine, untuk memperdalam pemahaman mengenai salah satu model komputasi yang mendasar dan pengenalan Internet of Things (IOT), desain vending machine ini akan menggunakan metode finite state automata (FSA). Dengan desain finite state automata, penelitian ini telah menghasilkan desain vending machine logam mulia berbasis Internet of Things (IOT) dari cara login ke vending machine sampai fisik logam mulia dapat diterima. Produk penjualan logam mulia dengan menggunakan vending machine ini diharapkan dapat menjangkau masyarakat lebih luas untuk berinvestasi, khususnya logam mulia.
\end{abstract}

Kata kunci: Internet of Things, logam mulia, vending machine

Abstract: Saving gold is an investment that is considered a safe haven, in the midst of today's modern era saving gold can be done in installments, while the problem is the concern when the physical gold cannot be physically withdrawn which creates the potential for fraud or fraudulent investments that are currently rampant. to overcome this problem the sale of precious metals can be developed to be more attractive with vending machines, to deepen understanding of one of the fundamental computing models and the introduction of the Internet of Things (IOT), this vending machine design will use the finite state automata (FSA) method. With the design of finite state automata (FSA), this research has resulted in the design of a gold vending machine based on the Internet of Things (IOT) from how to login to the vending machine until the gold is physically acceptable. The product selling gold using vending machines is expected to reach a wider audience to invest, especially gold.

Keywords: Internet of Things, precious metals, vending machine

\section{Pendahuluan}

Menabung merupakan hal yang umum pada saat ini, tetapi menabung dalam bentuk uang sudah tidak jaman lagi karena tidak sebanding dengan inflasi per tahunnya, investasi menjadi sebuah alternatif yang cocok dibandingkan menabung, namun saat ini investasi sangat 
bervariasi, mulai dari investasi logam mulia, saham, reksadana, forex sampai cryptocurrency. Dan investasi yang masih paling dipercaya aman oleh semua kalangan adalah investasi logam mulia, untuk berinvestasi di logam mulia diharuskan kita untuk ke toko emas, lembaga penjual emas, atau ke pegadaian. Karena satuan logam mulia minimal $1 \mathrm{gram}$ dengan harga saat ini sekitar Rp.950.000,-, tidak menjangkau banyak orang yang ingin membeli logam mulia, dan pengambilan logam mulia fisik yang harus diambil di kantor penyedia layanan tersebut.

Membuat sebuah sistem dengan Internet of Things (IoT) yang mengikutsertakan sistem operasi (OS) Android atau IOS berarti sistem yang dibuat tersebut akan dapat mencakup pengguna dalam sebagian besar masyarakat di dunia[1]. Pemilihan vending machine logam mulia mencoba menjadi solusi untuk pengambilan logam mulia dimana saja dan kapan saja, memudahkan mereka mendapatkan fisik logam mulia dimanapun seperti mengambil uang pada ATM.

Dengan desain vending machine berbasis IoT dan terintegrasi aplikasi smartphone yang sudah daring dimulai dari mendaftar sebagai pengguna di aplikasi, verifikasi KTP, dan setelah selesai verifikasi, pengguna baru bisa melakukan transaksi seperti isi saldo, pembelian logam mulia dan penjualan logam mulia, pembelian logam mulia pada aplikasi mulai dari Rp.10.000, ketika akumulasi saldo sudah mencapai minimal 1 gram, fisik logam mulia dapat diambil pada VM sesuai dengan jumlah saldo logam mulia yang dimiliki,

Desain ini memanfaatkan loT, karena dengan teknologi loT pengembang aplikasi dan vending machine dapat berkolaborasi dengan pengembang aplikasi untuk melakukan verifikasi seperti jumlah saldo logam mulia yang dimiliki, verifikasi wajah untuk memastikan pengambilan logam mulia diambil oleh orang yang bersangkutan yang menggunakan face recognition yang disesuaikan pada database server untuk data pengguna sesuai pada saat melakukan pendaftaran, serta untuk mengontrol otomatis dari mesin untuk mengeluarkan fisik logam mulia yang sesuai misalnya logam mulia $1 \mathrm{gram}, 5 \mathrm{gram}, 10 \mathrm{gram}$ dengan menggunakan Arduino board atau Raspberry pi yang saat ini sudah banyak beredar dipasaran.

Untuk membuat sistem otomatis tidak terlepas dari teknologi, Teknologi adalah sebuah alat yang dibuat oleh manusia yang berfungsi untuk membantu manusia saat melakukan suatu aktivitas. Dengan menggunakan teknologi pada bidang industri dapat membuat produksi barang lebih banyak, produksi yang lebih stabil, dan memiliki hasil dengan kualitas yang lebih baik [2]. Komputer dan perangkat lunak sering dianggap sebagai hal yang rumit oleh masyarakat. Tetapi seiring perkembangan jaman, komputer selalu memiliki peran yang penting untuk setiap bidang kehidupan manusia dan perkembangan teknologi [3].

Sistem otomatis merupakan sebuah sistem yang akan bekerja secara terus menerus dan mandiri tanpa harus dikendalikan oleh manusia.[4] salah satu mesin otomatis yang sedang berkembang dimasyarakat saat ini adalah vending machine, walaupun pengembangan mesin vending ini sudah lama sekali digunakan sebagai salah satu alternatif penjualan produk dengan tujuan untuk dapat mengurangi pengeluaran biaya untuk membayar gaji karyawan karena tidak dibutuhkan personil yang khusus untuk mengoperasikan mesin, biaya sewa lokasi penjualan, biaya penggunaan listrik, dan/atau bahkan biaya membangun tempat penjualan produk seperti gerai atau kios [5].

Bagian dari sebuah vending machine yaitu bagian catu daya, elektronik, mekanik dan perangkat lunak. Pada bagian elektronik, terdapat mikrokontroler dan perangkat lunak untuk menjalankan alur kerja perangkat. Kemudian mekanik untuk menghantarkan barang ke pelanggan setelah dipicu oleh perangkat elektronik [6]. Di Indonesia, keberadaan vending machine semakin berkembang terutama dikota-kota besar. Oleh karena itu, munculah keinginan untuk mencoba mempelajari cara kerja vending machine sekaligus menerapkan bagian dari Teori Bahasa dan Automata untuk merancang dan membuat simulasinya [7].

Finite automata (FA) meliputi state dan transisi yang dapat menerima input dan menghasilkan ouput. FA memiliki himpunan state dan aturan untuk bergerak dari state satu ke state lain tergantung input simbol yang diberikan. Dengan abjad sebagai input yang diijinkan, FA memiliki state awal dan state akhir yang diterima [8], Terdapat 2 jenis untuk membedakan finite automata, yaitu DFA (Deterministic Finite Automata) dan NFA (Non-deterministic Finite Automata) [2]. NFA yaitu berbasis matematika adalah teknik yang memiliki model mesin abstrak yang bisa direpresentasikan atau divisualisasikan dengan menggunakan diagram. Model seperti itu bisa digunakan untuk melakukan perhitungan dengan input yang bergerak melalui serangkaian urutan transisi dan konfigurasi [10]. 
Teori automata adalah teori terkait mesin-mesin abstrak, dan berkaitan erat dengan teori bahasa formal [11]. State diagram ini akan menjadi dasar dalam pendefinisian tupel dan perancangan flowchart program nantinya. Jenis state diagram yang digunakan yaitu mealy machines dengan konsep Non-Deterministic Finite Automata (NFA). Dengan mealy machines akan terlihat output yang dikeluarkan pada setiap transisi antar state yang terjadi berdasarkan inputan yang diterima dan state sebelumnya [12].

Prinsip kerja FSA pada umumnya sebagai berikut: (1) FSA dapat menerima input berupa string, (2) FSA membaca state awal dengan kontrol sesuai dengan kondisi awal, (3) FSA menggunakan kontrol dan karakter awal yang telah dipindai, state akan pindah ke kondisi yang baru, (4) Proses FSA ini berlanjut sampai semua karakter dipindai atau dibaca, (5) Jika keadaan terakhir berada di set keadaan akhir yang telah ditentukan, maka string akan diterima atau dikenali oleh FSA. Jika tidak, maka string akan ditolak atau tidak dikenali oleh FSA [13].

Penggunaan automata secara umum pada perangkat lunak terutama pada pembuatan kompiler bahasa pemrograman. Bahasa pemprograman pada FSA bertindak sebagai sarana komunikasi antara manusia dan permasalahannya dengan komputer, yang dipakai untuk membantu memperoleh pemecahan masalah [14]. Dengan teknologi ini, sehingga dimungkinkan sebuah komputer mampu berkomunikasi dan berinteraksi dengan manusia tidak hanya melalui tulisan saja, namun juga dalam bentuk lisan menggunakan bahasa yang digunakan sehari-hari [15].

Pada saat yang sama pembentukan identitas pada masyarakat pun berlangsung secara kontestatif untuk mendefinisikan siapa mereka: disatu sisi mereka menjadi bagian dari suatu entitas general bangsa Indonesia dan di sisi lain terabaikan secara sosial dan material [16].

Penelitian ini bertujuan untuk mempermudah masyarakat untuk berinvestasi fisik emas serta memperdalam pemahaman mengenai cara kerja sebuah vending machine logam mulia yang dapat diintegrasikan dengan aplikasi smartphone.

\section{Metode Penelitian}

Metodologi yang ditetapkan pada penelitian ini akan disajikan menjadi empat tahap, dikarenakan metode penelitian ini bukan berdasarkan kebutuhan user dan belum sampai tahap purwarupa atau prototipe, maka: 1) tahap pertama yang dilakukan adalah design Finite State Automata (FSA) untuk diimplementasikan pada VM yang dapat berfungsi sebagai proses pengendalian distribusi logam mulia dari input hingga output yang teritegrasi dengan loT, 2) kemudian tahap selanjutnya melakukan perancangan sistem VM dimana pada tahap ini akan digambarkan secara detail proses menggunakan flowchart tentang cara kerja dari VM berdasarkan desain finite state automata pada tahap pertama untuk dapat dibuat rancangan aplikasi dan vending machinenya, 3) Tahapan berikutnya adalah melakukan desain aplikasi yang akan digunakan oleh pengguna, dengan desain apliksi yang dapat terintegrasi pada vending machine beserta ilustrasi tampilan antarmuka yang akan digunakan oleh pengguna sehingga dapat memudahkan pemahaman terkait desain aplikasinya, 4) Setelah desain aplikasi maka yang akan dilanjutkan dengan desain vending machine itu sendiri dengan penggunaan perangkat-perangkat yang umum berada dipasaran, akan dimanfaatkan untuk merakit vending machine secara elektrikal dan mekanikal untuk proses distribusi fisik logam mulia yang akan diterima oleh para pengguna, tetapi dalam penelitian ini belum dijelaskan sampai tahap implementasi dan evaluasi.

\section{Hasil dan Pembahasan \\ Finite State Automata}

Dalam hasil dan pembahasan pada point ini yang pertama dilakukan adalah membuat state diagram sebagai model sistem vending machine. Diagram state akan menjadi dasar dalam pendefinisian perancangan flowchart di tahapan selanjutnya. Dapat dilihat pada tabel 1. untuk tipe produk ada 3 jenis tipe produk dan harga, tetapi untuk pengguna yang ingin melakukan pembelian, pembelian hanya dapat dilakukan pada aplikasi, sedangkan untuk vending machine hanya sebagai alat untuk melakukan pengambilan fisik logam mulia, sehingga jumlah logam mulia yang diambil pada vending machine harus sesuai dengan jumlah saldo logam mulia yang ada pada aplikasi 
Tabel 1. Tipe Produk dan Harga

\begin{tabular}{clll}
\hline No & & Harga & Produk \\
\hline 1 & Rp. 950.000 & Logam Mulia 1gr & \\
\hline 2 & Rp. 4.750.000 & Logam Mulia 5gr & \\
\hline 3 & Rp. 9.500.000 & Logam Mulia 10gr & \\
\hline
\end{tabular}

Sumber: Hasil Penelitian (2021)

Sedangkan untuk identifikasi input, output dan state dijabarkan dalam tabel 2, dimana terdapat 7 state dan 1 output yang akan digambarkan dalam rancangan diagram state.

Tabel 2. Identifikasi State

\begin{tabular}{|c|c|c|}
\hline Kode & Uraian & Keterangan \\
\hline Q0 & State Aw al \& State Akhir & State \\
\hline Q1 & Validasi QRCode Login & State \\
\hline Q2 & Validasi Wajah & State \\
\hline Q3 & Menyiapkan Pecahan logam mulia $1 \mathrm{gram}$ & State \\
\hline Q4 & Menyiapkan Pecahan logam mulia 5 gram & State \\
\hline Q5 & Menyiapkan Pecahan logam mulia $10 \mathrm{gram}$ & State \\
\hline Q6 & Menyiapkan w adah & State \\
\hline Q7 & Mengeluarkan fisik logam mulia & Output \\
\hline
\end{tabular}

Sumber: Hasil Penelitian (2021)

Pada gambar 1 diagram state, dari proses awal hingga akhir merupakan proses yang ada pada vending machine saja, sehingga tidak ada penerimaan uang tunai pada diagram state, yang ada hanya menampilkan saldo yang ada pada aplikasi.

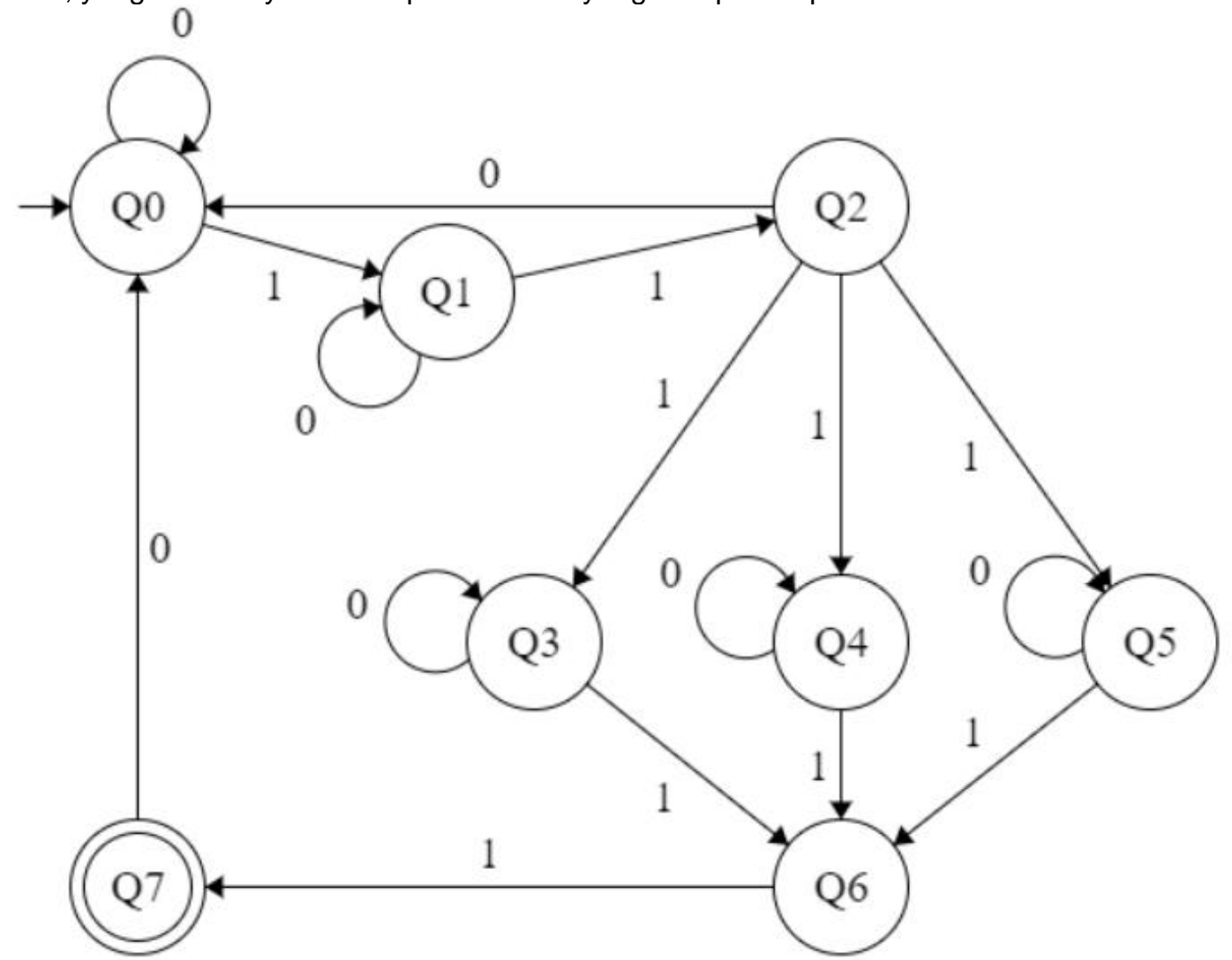

Sumber: Hasil Penelitian (2021)

Gambar 1. Rancangan Diagram State

Sehingga perubahan state dari state Q0 ke Q1 jika validasi QRCode untuk login ke vending machine dari aplikasi hanya jika sudah valid, jika belum valid maka proses tidak dapat dilanjutkan ke state berikutnya dan harus dimulai dari state Q0, proses selanjutnya jika QRCode sudah valid akan menuju proses dari Q1 ke Q2 dengan melakukan verifikasi wajah, jika belum valid maka akan Kembali lagi ke state sebelumnya yaitu melakukan verisikasi wajah ulang, setelah $Q R$ Code dan verifikasi wajah sudah valid tahap yang selanjutnya akan menampilkan 
jumlah saldo logam mulia yang sudah sesuai dengan jumlah saldo yang ada diaplikasi, dengan jumlah saldo logam mulia yang dapat ditarik fisiknya maka pada state Q2 pengguna akan diarahkan ke pemilihan pengambilan fisik logam mulia sesuai dengan jumlah saldo yang tersedia yang akan diarahkan ke state Q3/Q4/Q5, setelah pengguna memilih jenis logam mulia yang akan diambil, jika pengguna memilih logam mulia dengan pecahan 1gram maka akan dilanjutkan ke state Q3, jika pengguna memilih logam mulia dengan pecahan 5gram maka akan dilanjutkan ke state Q4 dan jika pengguna memilih logam mulia dengan pecahan 10gram maka akan dilanjutkan ke state Q5, setelah itu mesin akan mengirimkan informasi ke server untuk memotong saldo logam mulia pada aplikasi dan mesin akan masuk ke state berikutnya yaitu Q6 untuk menyiapkan fisik logam mulia yang akan diambil, Langkah berikutnya adalah Q7 dimana logam mulia akan dikeluarkan fisiknya, dan tampilan akan Kembali lagi ke state awal yaitu Q0.

Pada diagram state ini dapat dikembangkan lagi untuk jenis pecahan logam mulia yang dapat diambil oleh pengguna.

$$
\begin{aligned}
& \mathrm{S}=\{\mathrm{Q} 0\} \\
& \mathrm{Q}=\{\mathrm{Q} 0, \mathrm{Q} 1, \mathrm{Q} 2, \mathrm{Q} 3, \mathrm{Q} 4, \mathrm{Q} 5, \mathrm{Q} 6, \mathrm{Q} 7\} \\
& \mathrm{F}=\{\mathrm{Q7}\} \\
& \mathrm{S}=\{0,1\}
\end{aligned}
$$

\section{Perancangan Sistem}

Setelah membuat diagram FSA, maka tahap penelitian selanjutnya adalah membuat flowchart untuk system VM dan aplikasi yang terintegrasi, dapat dilihat pada gambar 2 .

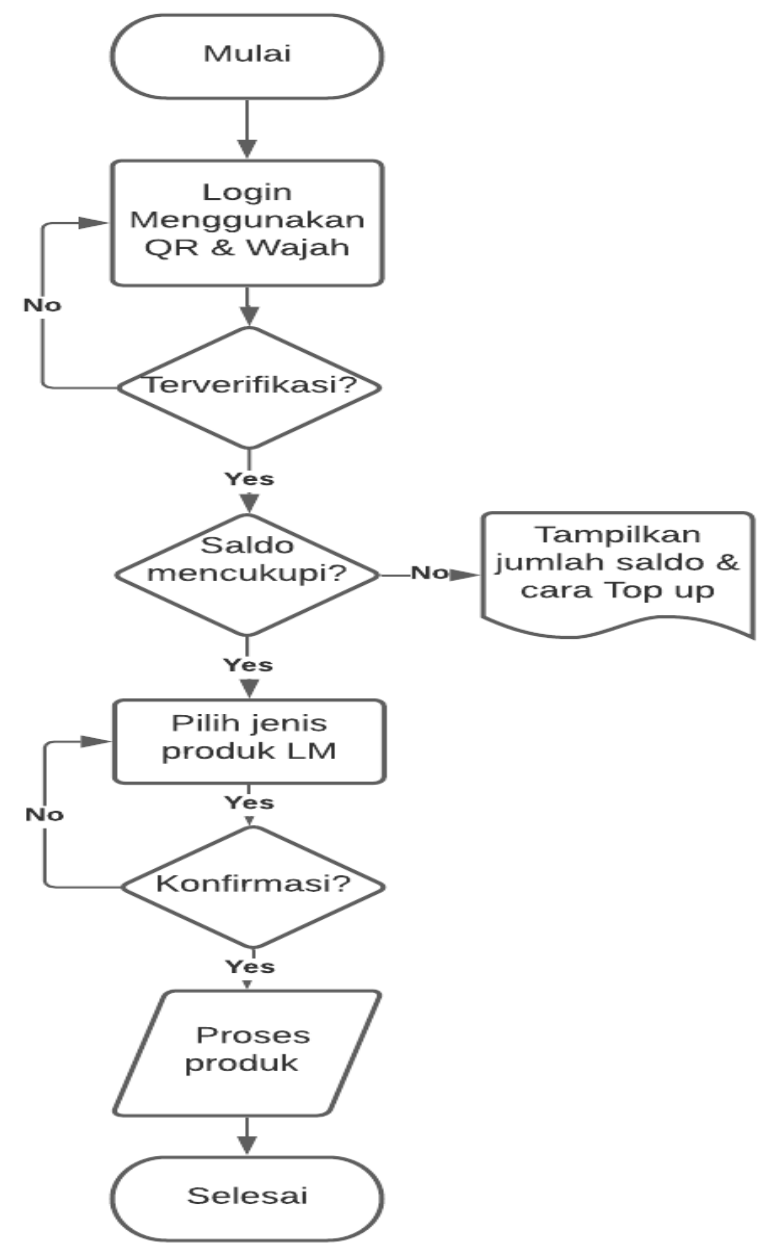

Sumber: Hasil Penelitian (2021)

Gambar 2. Rancangan Flowchart Vending Machine 
Berdasarkan gambar 2, diperlukan login pada VM dengan scan QRCode dan verifikasi wajah, setelah terverifikasi, sistem akan memproses jumlah saldo yang ada pada pengguna, lalu jumlah saldo logam mulia yang ada akan dihitung, apakah jumlah saldo logam mulia tersedia untuk memilih produk yang terdapat pada VM, jika sudah sesuai maka akan diteruskan untuk pemilihan produk logam mulia, setelah proses ini maka pengguna akan diminta untuk konfirmasi, jika setuju saldo pada aplikasi akan dipotong dan VM akan menyiapkan jenis produk logam mulia yang dipilih, setelah disiapkan maka pengguna dapat mengambilnya pada slot yang tersedia pada VM.

\section{Desain Aplikasi}

Pada tahap ini akan dibuat desain antarmuka aplikasi yang akan dipakai oleh pengguna, dimana pengguna akan disajikan tampilan awal berupa halaman login jika pengguna sudah mendaftar pada aplikasi, dan pendaftaran akun baru jika pengguna belum melakukan pendaftaran, dimana terdapat informasi-informasi penting yang harus diisi sebelum menggunakan aplikasi, seperti Nama, nomor handphone, alamat email, dan password.

Pada gambar 3 terdapat tampilan untuk masuk ke aplikasi dengan menggunakan nomor ponsel atau email serta tombol untuk pengguna baru yang ingin mendaftar akan di arahkan ke form baru dengan mengisi kelengkapan data, sebelum menggunakan aplikasi ini, pengguna diwajibkan melakukan verifikasi identitas dengan KTP dan verifikasi wajah yang harus sesuai dengan data yang terdaftar pada identitas yang digunakan.
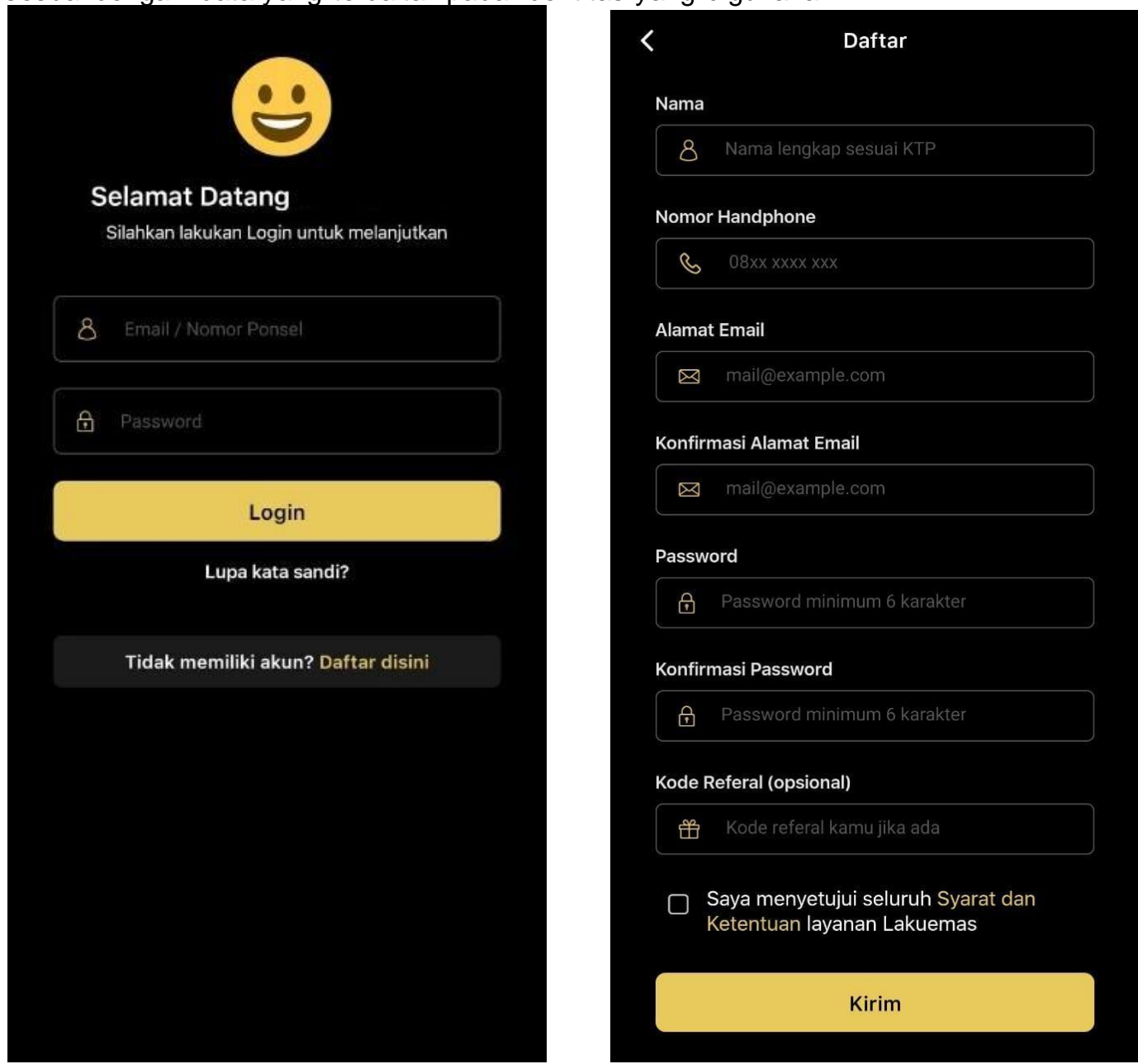

Sumber: Hasil Penelitian (2021)

Gambar 3. Desain Tampilan antarmuka untuk login dan registrasi

Sedangkan untuk melakukan login ke VM dapat dilihat pada gambar 4, pengguna harus berada didepan VM dan melakukan scan QR pada VM dari aplikasi yang sudah dilakukan login oleh pengguna, setelah dilakukan scan QRCode mesin akan menverifikasinya dengan teknologi 
face recognition atau scan wajah pada kamera yang terdapat di vending machine, untuk memastikan pengguna harus sesuai dengan data kepemilikan dan identitas pengguna yang terdaftar, Jika dalam proses scanning ini gagal, maka akan diulang hingga beberapa kali, pengguna juga dapat menggunakan e-KTP sebagai proses pengganti verifikasi wajah jika proses verifikasi wajah selalu gagal.

Setelah proses tersebut selesai dan terverifikasi, selanjutnya terdapat menu pada vending machine untuk melakukan penarikan fisik logam mulia, dimana pada tahap ini vending machine akan melakukan pengecekan pada total saldo emas yang harus mencukupi untuk menarik fisik logam mulia, setelah pengguna memilih produk logam mulia yang akan ditarik, maka tahap selanjutnya akan diproses oleh VM untuk mengeluarkan fisik logam mulia agar dapat diambil oleh pengguna. Setelah proses ini, pengguna akan diberikan notifikasi berupa SMS dan e-mail bahwa pengambilan fisik logam mulia telah berhasil.
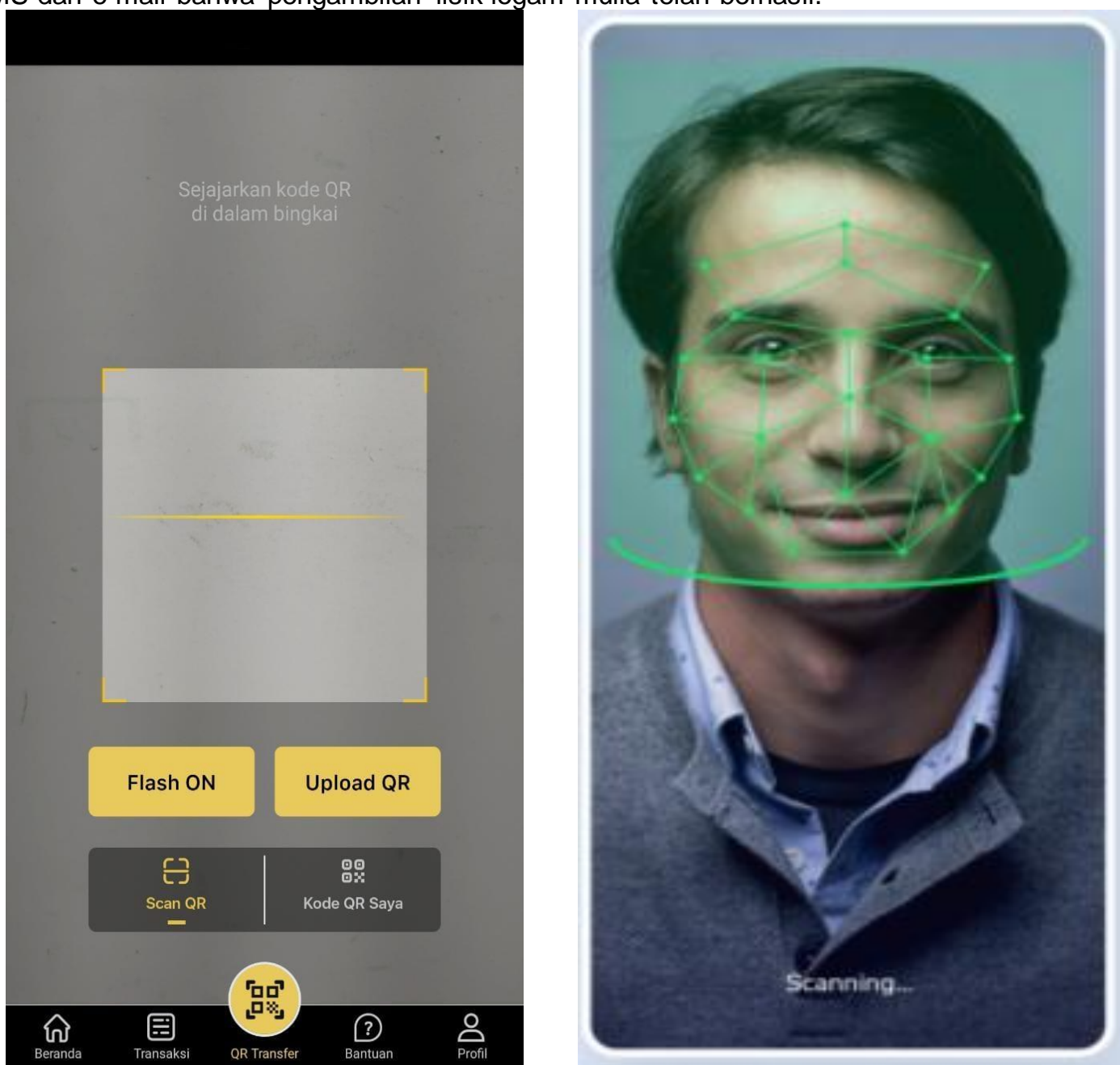

Sumber: Hasil Penelitian (2021)

Gambar 4. Login ke VM

\section{Desain Vending Machine}

Berdasarkan perancangan sistem yang sudah dibuat, pada bagian ini dibuat tampilan VM yang disesuaikan dengan fungsinya, menggunakan raspberry pi sebagai modul utama Internet of Things (loT), pi camera yang berfungsi pemindai wajah pengguna, NFC reader untuk scan KTP pengguna dan motor servo untuk mekanis yang terhubung dengan loT.

Pada Gambar 5 dapat dilihat bahwa prinsip kerja mesin otomatis atau vending machine ini sebagai berikut: Pada tahap awal, Pengguna melakukan login dengan cara menggunakan smartphone pada pengguna yang sudah login ke aplikasi lalu melakukan scan QRCode pada display VM yang berada pada tampilan display layar sentuh pada sebelah kanan VM dimana QRCode ini akan berubah setiap 30 detik untuk memastikan keamanan pengguna. 
Setelah pengguna melakukan scan QRCode pada VM dan sudah terverifikasi, maka VM akan meminta posisi wajah menggunakan pi camera dimana pengguna harus berada didepan kamera untuk melakukan scan wajah, jika proses verifikasi gagal terus menerus, maka mesin akan meminta untuk melakukan penyesuaian data dari KTP, dengan cara menempatkan e-ktp pengguna pada posisi yang ditempatkan pada NFC reader dibawah display layar VM. Jika verifikasi identitas sudah selesai,maka pengguna dapat memilih jenis produk yang akan diambil pada vending machine sesuai dengan stok yang tersedia, jika semua stok tersedia maka pengguna dapat mengambil dengan pecahan logam mulia $1 \mathrm{gram}, 5 \mathrm{gram}$ dan $10 \mathrm{gram}$, untuk mengambil logam mulia dengan pecahan yang tidak tersedia, misalnya ingin mengambil logam mulia sebanyak 7 gram, maka harus dilakukan proses pengambilan 3 kali, yaitu 5 gram, 1 gram dan 1 gram.

Setelah pengguna memilih pecahan fisik logam mulia yang akan diambil, VM akan memotong saldo pengguna yang kemudian mesin akan memutar motor servo untuk mengeluarkan produk yang dipilih, sehingga produk yang berada pada VM akan bergerak menuju ke penempatan dimana pengguna dapat mengambil fisik logam mulia pada slot pengambilan produk yang berada pada VM. Setelah proses ini selesai maka pengguna akan diberikan notifikasi berupa SMS dan e-mail sebagai laporan bahwa proses transaksi telah berhasil atau gagal.

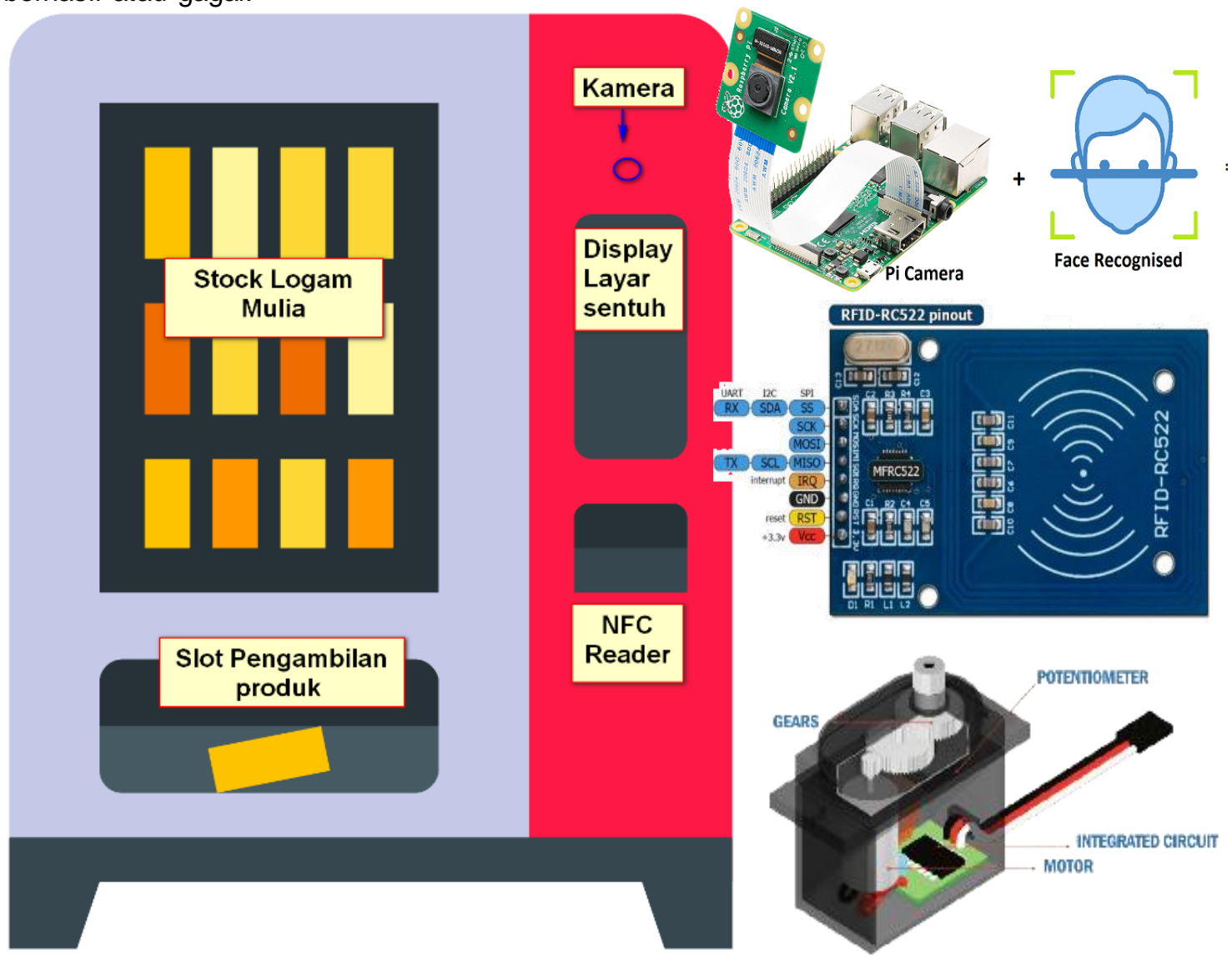

Sumber: Hasil Penelitian (2021)

Gambar 5. Desain Vending Machine

\section{Kesimpulan}

Perancangan desain vending machine logam mulia ini dapat mempermudah masyarakat untuk berinvestasi terutama fisik logam mulia, dengan menggunakan model komputasi dasar yang telah dijabarkan pada penelitian ini, dapat memperdalam pemahaman desain vending machine dengan menggunakan metode FSA. Hal ini telah dibuktikan dengan rancangan diagram state FSA pada VM logam mulia yang dapat menerima masukan dengan kondisi tertentu kemudian dapat menghasilkan keluaran sesuai dengan yang di harapkan. Dari desain FSA yang telah dibuat maka desain aplikasi dan VM logam mulia dapat dilanjutkan pada penelitian ini. Dikarenakan penelitian ini memanfaatkan perangkat keras microcontroller yang 
semakin banyak dipasaran saat ini seperti raspberry pi atau arduino beserta perangkat pendukung seperti motor servo, NFC reader, dan kamera yang dapat diintegrasikan sebagai otomatisasi pada vending machine membuat desain perangkat keras untuk otomatisasi ini menjadi lebih praktis. Sedangkan untuk keamanan pada VM yang didesain, keamanan yang dibuat sudah berlapis karena menggunakan pemindai wajah dan KTP sebelum pengguna dapat mengambil fisik logam mulia, serta notifikasi berupa SMS dan e-mail ke pengguna sebagai laporan transaksi berhasil atau gagal. Diharapkan dengan adanya vending machine logam mulia ini dapat meningkatkan pengalaman pengguna dalam menggunakan vending machine, serta meningkatkan perkembangan mesin otomatis di Indonesia, serta dengan semakin banyaknya mesin otomatis dan kepercayaan pengguna, dapat juga meningkatkan keinginan masyarakat yang lebih luas lagi untuk berinvestasi khususnya logam mulia, selanjutnya untuk desain rancangan FSA dan vending machine ini dapat dikembangkan lagi secara fleksibel dengan tidak terpaku terhadap barang yang dijual, perangkat yang digunakan serta sistem ada. Bahwa kreatifitas dan ide yang muncul dapat dikembangkan dan ditingkatkan lagi menjadi lebih berguna dan lebih bermanfaat untuk seluruh lapisan masyarakat didunia, terutama di Indonesia.

\section{Referensi}

[1] H. K. Andrew Kurniawan Sulisthio, Yulia, "Pembuatan Perangkat dan Aplikasi Sistem Vending Machine Berbasis Arduino Leonardo dan Android," J. Infra, 2016.

[2] Fergie Joanda Kaunang, "Penerapan Konsep Finite State Automata ( FSA ) pada Mesin The Implementation of Finite State Automata in an Automatic Ice cream Maker Machine," Penerapan Konsep Finite State Autom. pada Mesin Pembuat Ice cream Otomatis, vol. 9, no. 2, pp. 129-137, 2019.

[3] C. S. Aji, E. A. Sarwoko, and R. Saputra, "Aplikasi Konversi Aksara Latin Ke Aksara Jawa Menggunakan Finite State Automata Dengan Visual Basic," J. Informatics Technol., vol. 1, no. 3, pp. 52-66, 2014.

[4] R. Pradana Putra, I. G. A. P. Raka Agung, and P. Rahardjo, "Rancang Bangun Vending Machine Menggunakan Qr Code Berbasis Mikrokontroler," J. Spektrum, vol. 6, no. 2, p. 102, 2019, doi: 10.24843/spektrum.2019. W6.i02.p15.

[5] P. Handoko, H. Hermawan, and S. Jaya, "Reverse Vending Machine Penukaran Limbah Botol Kemasan Plastik Dengan Tiket Sebagai Alat Tukar Mata Uang," Semin. Nas. Sains dan Teknol. 2018, pp. 1-12, 2018.

[6] Y. P. Wijaya, "Mesin Penjual Softdrink Otomatis Berbasis ATMega8535," J. Elektro dan Mesin Terap., vol. 1, no. 2, pp. 29-38, 2015, doi: 10.35143/elementer.v1i2.42.

[7] A. S. Maulana, "Implementasi Finite State Automata (FSA) dengan Simulasi Vending Machine pada Aplikasi Android," J. Edukasi Elektro, vol. 3, no. 2, pp. 110-120, 2020, doi: 10.21831/jee. Bi2.28332.

[8] R. A. Nugraha, A. Mulyani, and W. Gata, "Desain Vending Machine Rujak Buah Dengan Finite State Automata," IJCIT (Indonesian J. Comput. Inf. Technol., vol. 5, no. September, pp. 198-207, 2020.

[9] R. Hariyanto, P. Studi, T. Informatika, F. T. Informasi, and U. M. Pasuruan, "Sistem Pakar Diagnosis Penyakit dan Hama Pada Tanaman Tebu Menggunakan Metode Certainty Factor," vol. 3, no. 1, pp. 1-4, 2018, doi: 10.31328/jo.

[10] A. Faisal, G. V. Saragih, and W. Gata, "Desain Vending Machine Rokok Dengan Mengimplementasikan Finite State Automata Terintegrasi Dengan E-KTP," Matics, vol. 12, no. 1, p. 55, 2020, doi: 10.18860/mat.v12i1.8693.

[11] R. A. Ma'arif and F. Fauziah, "Implementasi Finite State Automata (FSA) dalam Proses Pengisian Kartu Rencana Studi," JOINTECS (Journal Inf. Technol. Comput. Sci., vol. 3, no. 3, pp. 115-120, 2018, doi: 10.31328/jointecs.Vi3.816.

[12] B. Richardson, K. Hendy, V. Andiyani, and W. Philips, "Penerapan Konsep NonDeterministic Finite Automata (NFA) pada Aplikasi Simulasi Mesin Kopi Vending," J. Inform. Univ. Pamulang, vol. 4, no. 1, p. 1, 2019, doi: 10.32493/informatika.v4i1.2062.

[13] F. Utdirartatmo, Teori Bahasa dan Otomata. Yogyakarta: Graha IImu, 2005.

[14] J. C. Irawan, I. M. A. Pakereng, and R. Somya, "Perancangan dan Implementasi Finite Automata pada Simulasi Vending Machine," D'cartesian, vol. 1, no. 1, p. 42, 2012, doi: 10.35799/dc.1.1.2012.534. 
[15] R. A. W., H. Tolle, and O. Setyawati, "Pengembangan Aplikasi Text-to-Speech Bahasa Indonesia Menggunakan Metode Finite State Automata Berbasis Android," J. Nas. Tek. Elektro dan Teknol. Inf., vol. 5, no. 1, 2016, doi: 10.22146/jnteti.v5i1.179.

[16] I. A. D. Intan Pemata Sari, "Politik Identitas Masyarakat Perbatasan Indonesia-Malaysia: Kasus Badau Di Kapuas Hulu, Kalimantan Barat," J. Kawistara, vol. 4, no. 3, 2014, doi: 10.22146/kawistara.6378. 